\title{
PERSEPSI MASYARAKAT TEPIAN SUNGAI TERHADAP PEMANFAATAN RUANG SIRKULASI DAN RUANG TERBUKA SEBAGAI RESPON MITIGASI BENCANA BERBASIS BENCANA AIR DI SINTANG
}

\author{
Bontor Jumaylinda Br. Gultom
}

Program Studi Arsitektur, Universitas Tanjungpura, Pontianak

bontor_jl@teknik.untan.ac.id

\section{Tri Wibowo Caesariadi}

Program Studi Arsitektur, Universitas Tanjungpura, Pontianak

tricaesariadi@teknik.untan.ac.id

\begin{abstract}
Abstrak
Sintang merupakan salah satu kota di Kalimantan Barat yang berada di pertemuan dua sungai, yaitu sungai Kapuas dan Sungai Melawi. Kelurahan Kapuas Kiri Hilir, Kelurahan Menyumbung Tengah dan Kelurahan Ulak Jaya merupakan kawasan permukiman padat yang sudah ada sejak lama di Sintang, dekat dengan pusat historis Kota Sintang yaitu Keraton Sintang dan tetap eksis sampai sekarang. Sedangkan kondisi dunia yang sedang mengalami pemanasan global mengakibatkan kawasan-kawasan yang berhubungan langsung dengan air rentan mengalami kenaikan permukaan air sungai (pasang air). Mengingat mahalnya harga nyawa manusia maka diperlukan penelitian pada pemanfaatan ruang sirkulasi dan ruang terbuka untuk mitigasi bencana berbasis bencana air ketiga kelurahan tersebut.

Penelitian ini bertujuan mengidentifikasi dan mengilustrasikan model mitigasi bencana berbasis bencana air (hydrometeorological disaster), dilihat dari persepsi masyarakat dan pemanfaatan ruang sirkulasi dan ruang terbuka.

Penelitian ini dilakukan menggunakan pola pikir induktif yaitu berpikir berlandaskan pandangan khusus ke umum. Teknik pengumpulan data, pengolahan data, dan analisis dilakukan dengan membandingkan metode kuantitatif dan kualitatif. Kuantitatif digunakan untuk mengukur persepsi masyarakat akan bencana berbasis bencana air. Sedangkan metode kualitatif mendeskripsikan dalam bentuk ilustrasi pemanfaatan ruang terbuka dan sirkulasi.

Hasil penelitian persepsi masyarakat disimpulkan bahwa bencana yang sering terjadi adalah bencana kenaikan permukaan air (banjir/pasang). Masyarakat juga berpendapat walaupun mereka menghadapi kemarau, namun dampaknya tidak terlalu terasa karena mereka sudah mengantisipasi dengan menyediakan tempat penampungan air. Dan berdasarkan kondisi fisik lapangan, model mitigasi bencana berupa jalur sirkulasi berupa titian (papan kayu).
\end{abstract}

Kata-kata Kunci: mitigasi, bencana, persepsi, ruang, sirkulasi 


\title{
THE PERCEPTION OF RIVERBANK COMMUNITY ON UTILIZATION OF CIRCULATION AND OPEN SPACE AS DISASTER MITIGATION RESPONSE BASED ON WATER DISASTER IN SINTANG
}

\begin{abstract}
Sintang is one of the cities in West Kalimantan which lies in the confluence of two rivers, i.e. Kapuas River and Melawi River. Kapuas Kiri Hilir Village, Menyumbung Tengah Village and Ulak Jaya Village have been densely populated residential areas in Sintang for a long time, located close to the historical centre of Sintang i.e. Sintang Palace and still exists today. While the condition of the world that is experiencing global warming has resulted in areas that are directly related to water susceptible to rising water levels (tidal water). Given the value of human life, research is needed on the use of the circulation space and open space for disaster mitigation based on water in the three villages.

This study aims to identify and illustrate a model of water disaster-based mitigation (hydrometeorological disaster), seen from the public perception and utilization of circulation and open space.

This research was conducted using an inductive mindset, which is thinking based from specific detail to general truth. Data collection techniques, data processing, and analysis were carried out by comparing quantitative and qualitative data. Quantitative was used to measure people's perceptions of disaster based on water-disaster. Whereas qualitative method described the illustration of open space and circulation.

The results of the research on community perceptions concluded that disaster that often occurs is disaster of rising water levels (flood / tide). The community also believes that even though they face droughts, the impact is not too pronounced because they have anticipated it by providing water reservoirs. And based on the physical field condition, the suitable disaster mitigation model is circulation paths in the form of wooden board.
\end{abstract}

Keywords: mitigation, disaster, percention, space, circulation

\section{Pendahuluan}

Indonesia adalah negara kepulauan yang tercatat memiliki 17.000 lebih kepulauan. Berdasarkan data Kementerian Dalam Negeri Tahun 2010, jumlah pulau yang dimiliki Indonesia adalah 17.504 pulau. Hal ini mengindikasi bahwa sebagian besar wilayah di Indonesia berhubungan langsung dengan air. Dan Kondisi tersebut juga menyumbang ancaman. Salah satunya yaitu pemanasan global. Menurut Wardhana (2010, hal.48), pemanasan global adalah meningkatnya suhu permukaan bumi. Temperatur yang lebih hangat tersebut menimbulkan problem lain, seperti naiknya ketinggian laut naik drastis (sea level rise), peningkatan curah hujan disertai cuaca ekstrem dengan frekuensi yang lebih besar. Yang menyebabkan bencana banjir.

Mengingat bahwa bencana akan menyebabkan kerugian yang sangat besar, yaitu korban jiwa manusia, kerusakan lingkungan, kerugian harta benda, dan dampak psikologis yang dalam, serta meninjau data bencana yang sering terjadi, Pemerintah Republik Indonesia telah membuat Undangundang tentang penanggulangan bencana. Dalam UU tersebut diatur bahwa diperlukan upaya untuk menghindari bencana tersebut. Upaya bisa dilakukan baik melalui pembangunan fisik maupun penyadaran dan peningkatan kemampuan menghadapi ancaman bencana.

Posisi keberadaan kota Pontianak yang berada di tepi Sungai Kapuas berdampak positif dan negatif. Dari segi Positif, masyarakat dapat memanfaatkan air sebagai sumber kehidupan. Segi negatifnya, kota akan memiliki potensi terkena dampak dari hydrometeorogical disaster. Pada 
musim hujan, air sungai akan pasang dan menggenangi bangunan permukiman masyarakat sekitar. Dan ketika musim kemarau, kebutuhan air bersih sangat diperlukan sekali untuk aktivitas dan kebutuhan sehari-hari.

Permasalahan di atas dialami pada beberapa tempat salah satunya adalah Kota Sintang yang berada dekat pada area hulu Sungai Kapuas. Kota Sintang memiliki bentuk geografis yang sama dengan Pontianak, yaitu terbelah oleh sungai menjadi 3 bagian kota. Terdapat pula pemukiman penduduk yang berada di tepian sungai, dan juga sering mengalami banjir. Lokasi pemukiman ini yaitu Kelurahan Kapuas Kiri Hilir, Kelurahan Menyumbung Tengah dan Kelurahan Ulak Jaya.

Ketika banjir ruang gerak masyarakat menjadi terbatas, namun mengingat bahwa masyarakat tidak meninggalkan permukiman hanya karena potensi bencana ini, dan mereka tetap beraktivitas seperti biasa, maka terdapat kemungkinan-kemungkinan pemanfaatan ruang seperti ruang sirkulasi dan ruang terbuka, ketika kejadian tersebut berlangsung. Tantangan besar ini yang merupakan landasan utama dalam penelitian ini, yaitu bagaimana caranya mengidentifikasi dan mengilustrasikan model mitigasi bencana berbasis bencana air (hydrometeorological disaster), dilihat dari persepsi masyarakat dan pemanfaatan ruang sirkulasi dan ruang terbuka di Kelurahan Kapuas Kiri Hilir, Kelurahan Menyumbung Tengah dan Kelurahan Ulak Jaya.

Berdasarkan latar belakang tersebut, tujuan dalam penelitian ini adalah mengidentifikasi bagaimana persepsi masyarakat di Kelurahan Kapuas Kiri Hilir, Kelurahan Menyumbung Tengah dan Kelurahan Ulak Jaya, terhadap potensi bencana berbasis air dengan pemanfaatan ruang sirkulasi dan ruang terbuka pada wilayah sekitar.

\section{Kajian Pustaka}

Menurut Undang-undang Republik Indonesia Nomor 24 tahun 2007 tentang Penanggulangan Bencana, bencana adalah peristiwa atau rangkaian peristiwa yang mengancam dan mengganggu kehidupan dan penghidupan masyarakat yang disebabkan, baik oleh faktor alam dan/atau faktor nonalam maupun faktor manusia sehingga mengakibatkan timbulnya korban jiwa manusia, kerusakan lingkungan, kerugian harta benda, dan dampak psikologis.

Menurut Rachmatullah, dkk (2016), bencana adalah suatu fenomena yang selalu terjadi di dunia sekarang ini dan bisa tejadi setiap saat. Dampak utama bencana terhadap manusia adalah kerugian besar yang terjadi baik di materi ataupun imaterial. Pada umunya, bencana yang paling sering terjadi adalah bencana tanah longsor, kebakaran hutan, gempa bumi dan terutama yang paling sering terjadi adalah bencana banjir.

Maka berdasarkan paparan teori di atas, bencana berbasis air (hydrometeorological disaster) adalah bencana yang diakibatkan proses alamiah atau fenomena atmosfir, hidrologikal atau kondisi laut yang menyebabkan kehilangan nyawa, luka, kerusakan properti, gejolak ekonomi dan sosial atau degradasi lingkungan; termasuk banjir, gelombang laut, tanah longsor, kemarau dan bencana yang berkaitan dengannya (suhu ekstrim dan kebakaran hutan).

\section{Mitigasi}

Menurut Subiyantoro (2010), mitigasi bencana sesungguhnya berkaitan dengan siklus penanggulangan bencana berupa upaya penanganan sebelum terjadinya bencana. Menurut Jokowinarno (2011), Mitigasi adalah merupakan tindakan-tindakan untuk mengurangi atau meminimalkan potensi dampak negatif dari suatu bencana. Sedangkan menurut Haifani (2008), Proses mitigasi bencana gempa adalah beberapa tindakan yang seharusnya diambil sebelum terjadinya suatu bencana yang mana hal itu terkait dengan tindakan secara struktural dan non struktural serta dalam rangka pengurangan resiko bencana yang terintegrasi dengan menggunakan sistem pengembangan yang berkelanjutan/sustainable development. Tujuan dari mitigasi bencana gempa bumi ini adalah untuk mengembangkan strategi mitigasi yang dapat mengurangi hilangnya kehidupan manusia dan alam sekitarnya serta harta benda, penderitaan manusia, kerusakan ekonomi 
dan biaya yang diperlukan untuk menangani korban bencana yang dihasilkan oleh bahaya gempa bumi.

Menurut Ishikawa dalam Wikantiyoso (2010), ada dua macam upaya mitigasi bencana gempa yakni, mitigasi struktur dan mitigasi non struktur. Mitigasi struktur adalah upaya dalam bentuk memperkuat bangunan dan/atau infrastruktur yang berpotensi terkena bencana, seperti membuat rekayasa struktur dan konstruksi untuk menahan serta memperkokoh bangunan ataupun membangun struktur bangunan penahan gempa dan sebagainya. Teknologi struktur bangunan beserta persyaratanpersyaratan keselamatan bangunan merupakan salah satu hal yang harus diperhatikan dalam upaya "mempersiapkan" ruang yang aman dan melindungi masyarakat kota. Urban landscape sebagai konfigurasi ruang kota dengan unsur bangunan tinggi, kepadatan bangunan, keberadaannya menjadi penting untuk mengurangi jumlah korban akibat gempa. Penataan urban landscape ini juga bertujuan untuk memberikan ruang untuk evakuasi, serta ruang penyelamatan korban gempa.

Maka berdasarkan paparan teori di atas, mitigasi adalah upaya mengurangi akibat bencana pada lokasi yang berpotensi sebelum terjadi bencana dengan mempersiapkan masyarakat untuk menghadapinya mengingatkan pentingnya nyawa manusia, dengan cara struktural, non struktural. Dalam penelitian ini, mitigasi yang dimaksud adalah menggali budaya lokal masyarakat setempat (struktural) dalam upaya mengurangi akibat bencana, berbentuk ilustrasi nilai budaya lokal.

\section{Sirkulasi dan Ruang Terbuka}

Menurut Carr dalam Haryanti (2008), ruang terbuka merupakan ruang wadah aktivitas sosial yang melayani dan juga mempengaruhi kehidupan masyarakat kota. Ruang terbuka juga merupakan wadah dari kegiatan fungsional maupun aktivitas ritual yang mempertemukan sekelompok masyarakat dalam rutinitas normal kehidupan sehari-hari maupun dalam kegiatan periodik.

Menurut Nazarudin dalam Haryanti (2008), ruang terbuka merupakan elemen vital dalam sebuah ruang kota karena keberadaannya di kawasan yang berintensitas kegiatan tinggi. Sebagai lahan tidak terbangun, ruang terbuka biasanya berada di lokasi strategis dan banyak dilalui orang.

Menurut Charles dalam Nugroho, dkk (2014), pola sirkulasi, rambu-rambu dan parkir merupakan salah satu pertimbangan penting untuk mencapai kesatuan dan kualitas lanskap. Sedangkan menurut Krier (1979), bahwa ruang publik dapat berbentuk memanjang (jalan, sungai, dll) dan persegi (lapangan, taman, dll).

\section{Persepsi}

Menurut Walgito (2004), persepsi adalah individu mengamati dunia luarnya dengan menggunakan alat indranya atau proses yang berwujud diterimanya stimulus oleh individu melalui reseptornya. Menurut Jalaluddin Rahmat (2004), persepsi adalah suatu pengalaman tentang objek peristiwa atau hubungan yang diperoleh dengan mengumpulkan informasi dan menafsirkan pesan.

Sarwono dalam Nurdiyana (2017), persepsi adalah kemampuan seseorang untuk mengorganisir suatu pengamatan, kemampuan tersebut antara lain kemampuan untuk membedakan, kemampuan untuk mengelompokkan, dan kemampuan untuk memfokuskan.

Maka berdasarkan paparan teori di atas, persepsi adalah suatu pengalaman tentang objek peristiwa yang dilihat dan dirasakan oleh seorang individu atau kelompok dalam pengamatan mereka dan membuat objek amatan yang dirasakan tersebut menjadi sebuah pandangan tersendiri. Maka dari itu, persepsi dapat berbeda antara satu individu dengan individu lainnya atau suatu kelompok dengan kelompok lainnya.

\section{Metode Penelitian}

Kabupaten Sintang terletak di bagian timur Provinsi Kalimantan Barat atau di antara $1^{\circ} 05^{\prime}$ Lintang Utara serta $0^{\circ} 46^{\prime}$ Lintang Selatan dan $110^{\circ} 50^{\prime}$ Bujur Timur serta $113^{\circ} 20^{\prime}$ Bujur Timur. Hal tersebut dapat disimpulkan bahwa wilayah Kabupaten Sintang dilalui oleh garis Khatulistiwa. 
Kelurahan Kapuas Kiri Hilir, Kelurahan Menyumbung Tengah dan Kelurahan Ulak Jaya juga berada di Kecamatan Sintang. Ketiga kelurahan ini terletak pada area tepian sungai. Ketiga kelurahan ini merupakan kawasan keraton, karena terdapat Keraton Sintang yang menjadi pusat sejarah Kota Sintang.

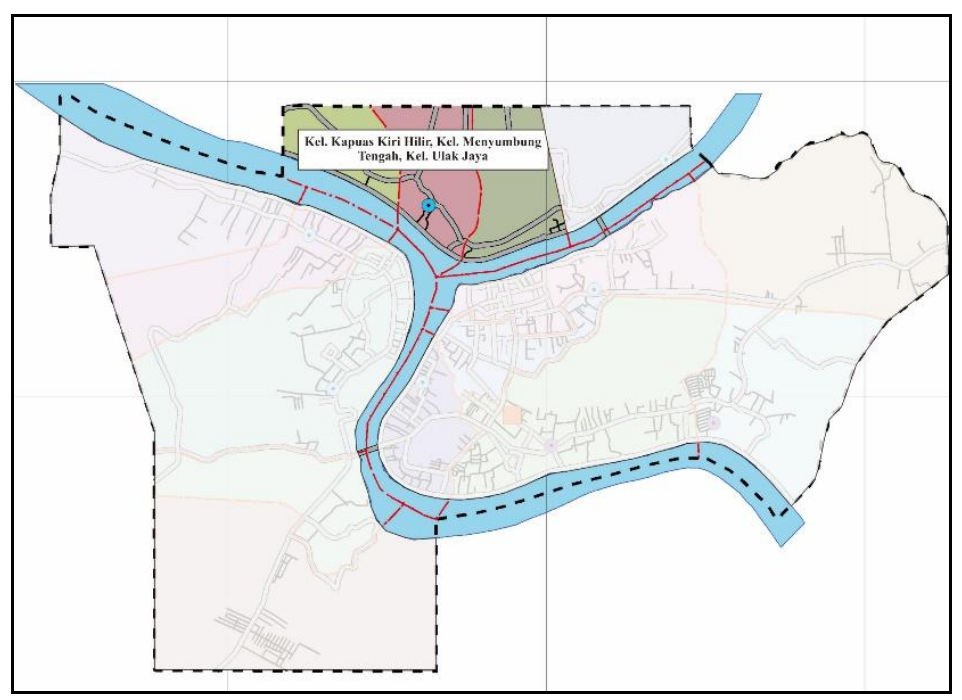

Gambar 1. Peta Administrasi Kecamatan Sintang (Kel. Kapuas Kiri Hilir, Kel. Menyumbung Tengah, Kel. Ulak Jaya)

Sumber: Bappeda Kabupaten Sintang, 2018

Penelitian ini dilakukan menggunakan pola pikir induktif yaitu berpikir berlandaskan pandangan khusus ke umum. Teknik pengumpulan data, pengolahan data, dan analisis dilakukan dengan membandingkan metode kuantitatif dan kualitatif. Kuantitatif digunakan untuk mengukur persepsi masyarakat akan bencana berbasis bencana air (menggunakan kuisioner), sedangkan metode kualitatif mendeskripsikan dalam bentuk ilustrasi pemanfaatan ruang sirkulasi dan ruang terbuka (Tabel 1).

Tabel 1. Variabel Penelitian

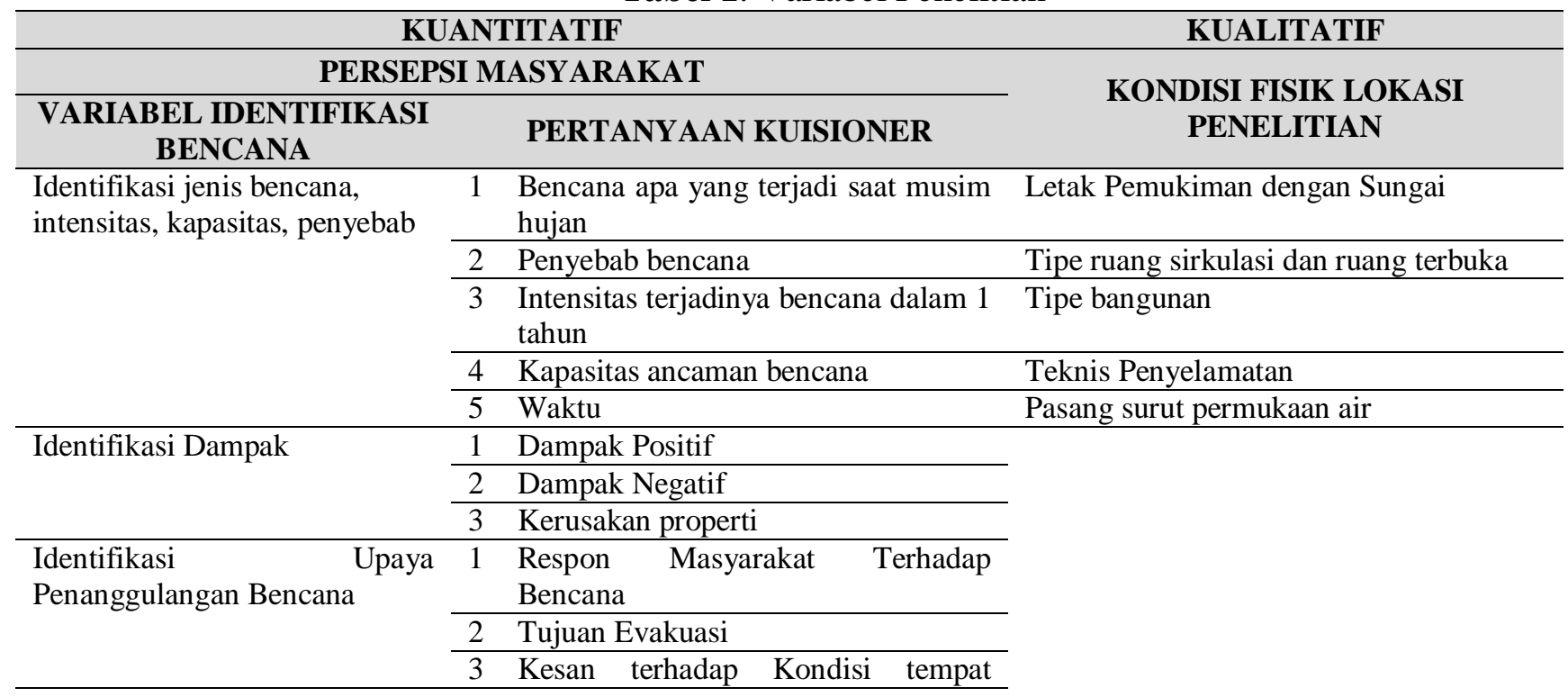




\begin{tabular}{lll}
\hline & \multicolumn{2}{l}{ evakuasi } \\
\cline { 2 - 3 } & 4 & Jarak lokasi evakuasi \\
\cline { 2 - 3 } & 5 & Pihak pemerhati evakuasi \\
\hline Identifikasi antisipasi & 1 & Upaya masyarakat \\
\cline { 2 - 3 } 2 & Ketersediaan lokasi evakuasi \\
\hline 3 & Sosialisasi untuk antisipasi bencana \\
\hline 4 & Ketersediaan Sistem peringatan \\
\hline
\end{tabular}

Sumber: Penulis, 2018

\section{Hasil dan Pembahasan} Identifikasi Potensi Bencana

Kawasan yang berpotensi rawan banjir adalah daerah yang berhubungan langsung dengan sungai. Daerah rawan banjir ini tersebar mengikuti ketinggian kontur pada level terendah. Terlihat pada area yang berwarna biru merupakan kawasan rawan banjir di Kota Sintang (Gambar 2).

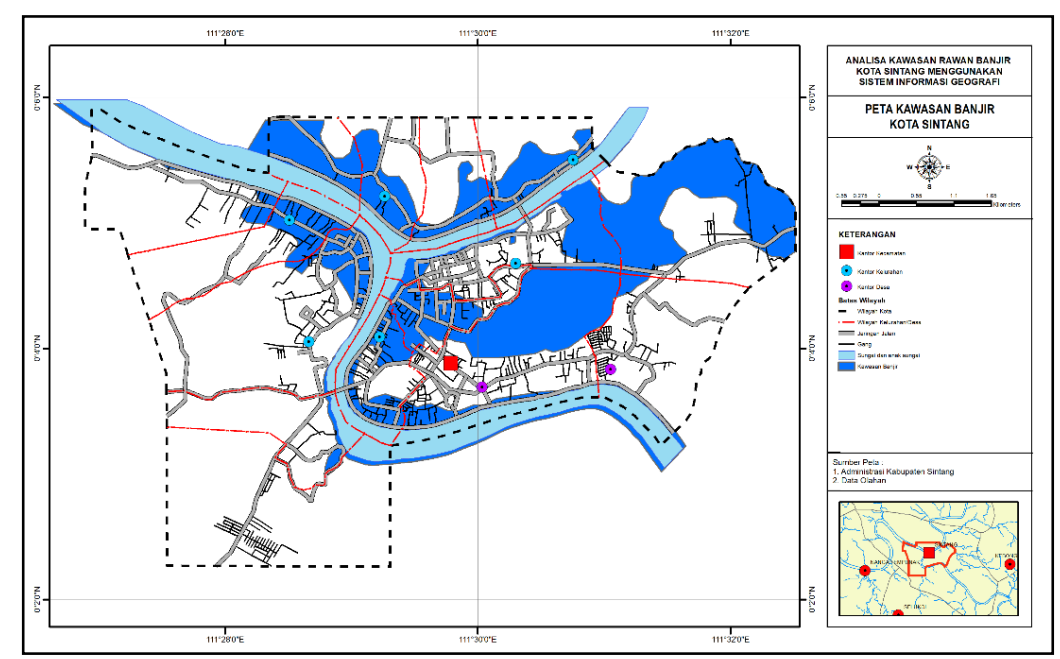

Gambar 2. Peta Kawasan Rawan Banjir di Kota Sintang Sumber: Bappeda Kota Sintang

\section{A. Persepsi Masyarakat}

Berdasarkan hasil kuisioner, dapat dirangkum persepsi masyarakat terhadap variabel bencana adalah seperti pada Tabel 2 .

Tabel 2. Persepsi Masyarakat

\begin{tabular}{|c|c|c|}
\hline \multirow{2}{*}{$\begin{array}{l}\text { VARIABEL } \\
\text { IDENTIFIKASI } \\
\text { BENCANA }\end{array}$} & \multicolumn{2}{|c|}{ PERSEPSI MASYARAKAT } \\
\hline & AIR BERLEBIHAN & KEKURANGAN AIR \\
\hline \multirow{4}{*}{$\begin{array}{l}\text { Identifikasi jenis bencana, } \\
\text { intensitas, kapasitas, } \\
\text { penyebab }\end{array}$} & Bencana Banjir & Kabut asap \\
\hline & $\begin{array}{l}\text { Intensitas banjir terjadi 1x dalam } \\
\text { setahun }\end{array}$ & Intensitas terjadi tidak menentu \\
\hline & $\begin{array}{l}\text { Kapsitas ir mencapai 1-2 meter diatas } \\
\text { permukaan jalan }\end{array}$ & Kapasitas asap tidak menentu \\
\hline & $\begin{array}{l}\text { Penyebab Banjir karena hujan terus } \\
\text { menerus dan mendapat limpahan air } \\
\text { dari kiriman hulu dan hilir sungai }\end{array}$ & $\begin{array}{l}\text { Penyebab Asap karena Kebakaran hutan, asap } \\
\text { industry dan karena tidak ada hujan }\end{array}$ \\
\hline \multirow[t]{2}{*}{ Identifikasi Dampak } & Banjir berdampak merusak & $\begin{array}{l}\text { Kabut asap berdampak negatif mengganggu } \\
\text { saluran pernapasan }\end{array}$ \\
\hline & Merusak bangunan, memakan korban & - \\
\hline
\end{tabular}




\begin{tabular}{|c|c|c|}
\hline & jiwa, dan kehilangan harta benda & \\
\hline & $\begin{array}{l}\text { Kerusakan bangunan pada bagian } \\
\text { tiang, tangga, lantai, dinding dan } \\
\text { pintu rumah }\end{array}$ & - \\
\hline \multirow{5}{*}{$\begin{array}{l}\text { Identifikasi Upaya } \\
\text { Penanggulangan Bencana }\end{array}$} & $\begin{array}{l}\text { Masyarakat menetap di rumah } \\
\text { masing-masing atau mengungsi ke } \\
\text { rumah keluarga }\end{array}$ & $\begin{array}{l}\text { Masyarakat menyimpan persediaan air cadangan } \\
\text { di drum/ember/tong }\end{array}$ \\
\hline & $\begin{array}{l}\text { Tidak terdapat tempat khusus } \\
\text { penyelamatan }\end{array}$ & - \\
\hline & $\begin{array}{l}\text { Menggunakan rumah masing-masing } \\
\text { atau rumah keluarga terdekat yang } \\
\text { tidak terkena banjir }\end{array}$ & - \\
\hline & Jarak tujuan 0-200 meter & - \\
\hline & Bantuan tidak merata & - \\
\hline \multirow{4}{*}{ Identifikasi antisipasi } & $\begin{array}{l}\text { Masyarakat melakukan kerja bakti } \\
\text { sebagai upaya penanggulangan } \\
\text { banjir }\end{array}$ & $\begin{array}{l}\text { Masyarakat menyimpan persediaan air cadangan } \\
\text { sekitar 1-5 drum/ember/tong per rumah }\end{array}$ \\
\hline & $\begin{array}{l}\text { Tidak terdapat tempat evakuasi } \\
\text { bencana }\end{array}$ & - \\
\hline & Tidak ada sosialisasi bencana & - \\
\hline & $\begin{array}{l}\text { Tidak terdapat system peringatan } \\
\text { banjir }\end{array}$ & - \\
\hline
\end{tabular}

Sumber: Penulis, 2018

\section{B. Kondisi Fisik Lokasi Penelitian}

\section{Letak Pemukiman dengan Sungai}

Letak pemukiman dengan sungai, dapat dilihat pada gambar, yaitu rata-rata memiliki jarak 15 meter dari bibir sungai, sehingga Kawasan ini memiliki banyak ruang untuk ruang terbuka dan sirkulasi. (Lihat Gambar 3)

\section{Tipe ruang sirkulasi dan ruang terbuka}

Tipe sirkulasi pada Kelurahan Kapuas Kiri Hilir, Kelurahan Menyumbung Tengah dan Kelurahan Ulak Jaya ada 2, yaitu sirkulasi jalan berupa aspal yang berada di tepi sungai (Lihat Gambar C, E, G, J dan L). Selain itu, terdapat sirkulasi jalan berupa Titian (kayu papan) yang menuju rumah apung di Sungai atau disebut juga Lanting (Lihat Gambar F). Sirkulasi jalan tersebut menjadi sirkulasi bagi masyarakat setempat dalam beraktivitas. Penataan antara jalur sirkulasi sirkulasi dengan ruang terbuka hijau menjadi suasana pada ketiga kelurahan ini menjadi asri dan bebas dalam bergerak. Penataan ruang terbuka hijau yang menjadi pelindung (buffer) antara sirkulasi jalan dan sungai (Gambar A, B, E, G dan L). Dan, terdapat ruang terbuka pendukung lainnya seperti pendopo yang dibangun di depan Keraton Almukarimah Sintang. (Gambar D).

Biasanya aktivitas yang dapat dilakukan pada permukiman di tepian sungai hanya dapat melakukan aktivitas seperti membuat tambak ikan (Gambar P), Tetapi, karena terdapat sirkulasi yang mudah, maka masyarakat Kelurahan Kapuas Kiri Hilir, Kelurahan Menyumbung Tengah dan Kelurahan Ulak Jaya dapat melakukan aktivitas lain, seperti beternak sapi (Gambar O) dan mendirikan tempat sarang walet (Gambar N). 


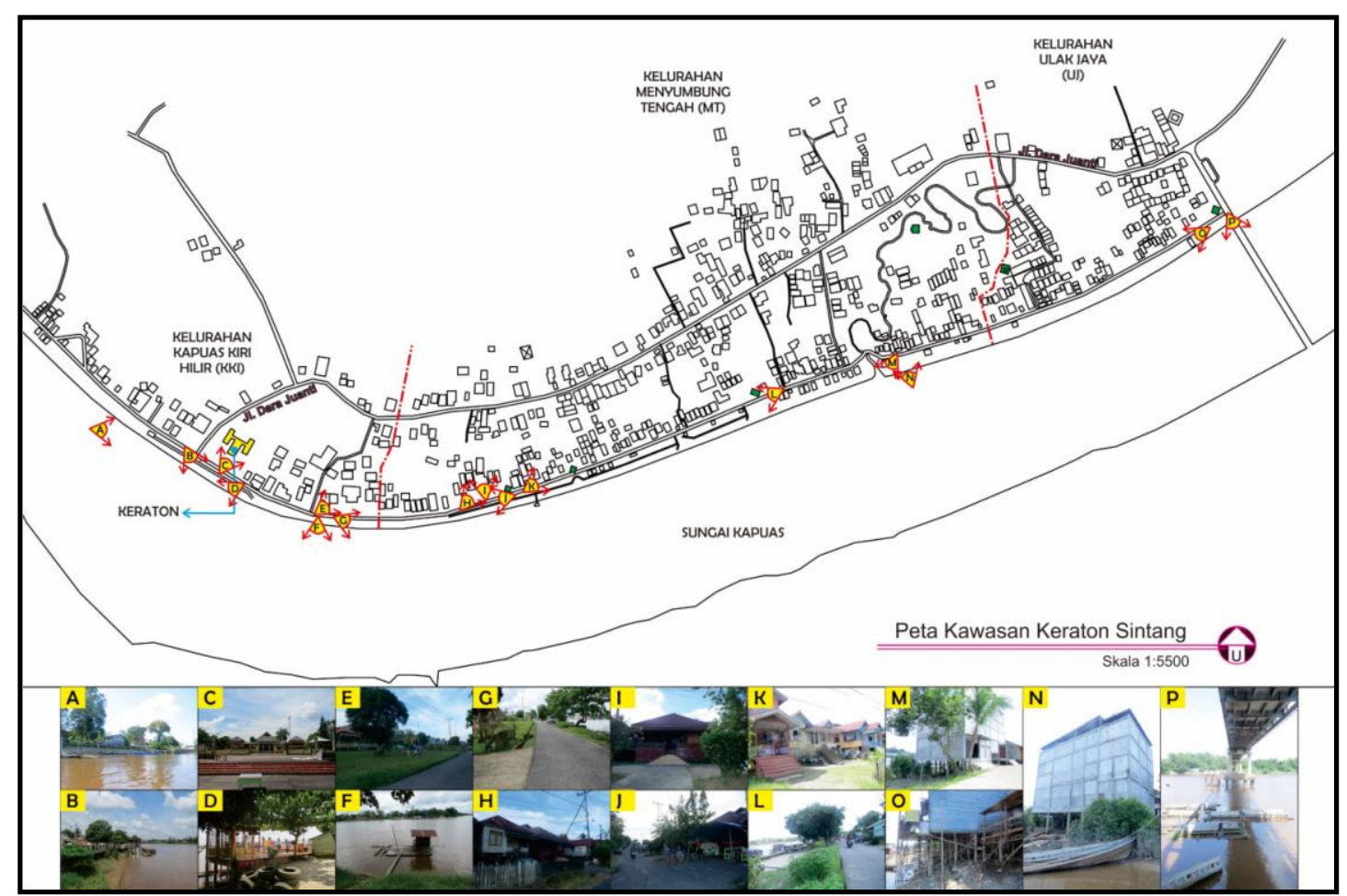

Gambar 3. Tipe Sirkulasi Jalan Aspal di Kelurahan Kapuas Kiri Hilir, Kelurahan Menyumbung Tengah dan Kelurahan Ulak Jaya Sumber: Dokumentasi Penulis, 2018

\section{Tipe bangunan}

Tipe bangunan di Kelurahan Kapuas Kiri Hilir, Kelurahan Menyumbung Tengah dan Kelurahan Ulak Jaya, ada 2 yaitu Tipe bangunan yang berada di darat (Gambar 4) dan tipe bangunan yang berada di bibir sungai (Gambar 4). Sedangkan tipe bangunan yang berada di atas air, yaitu Lanting (rumah terapung) yang tidak memiliki pondasi bawah.

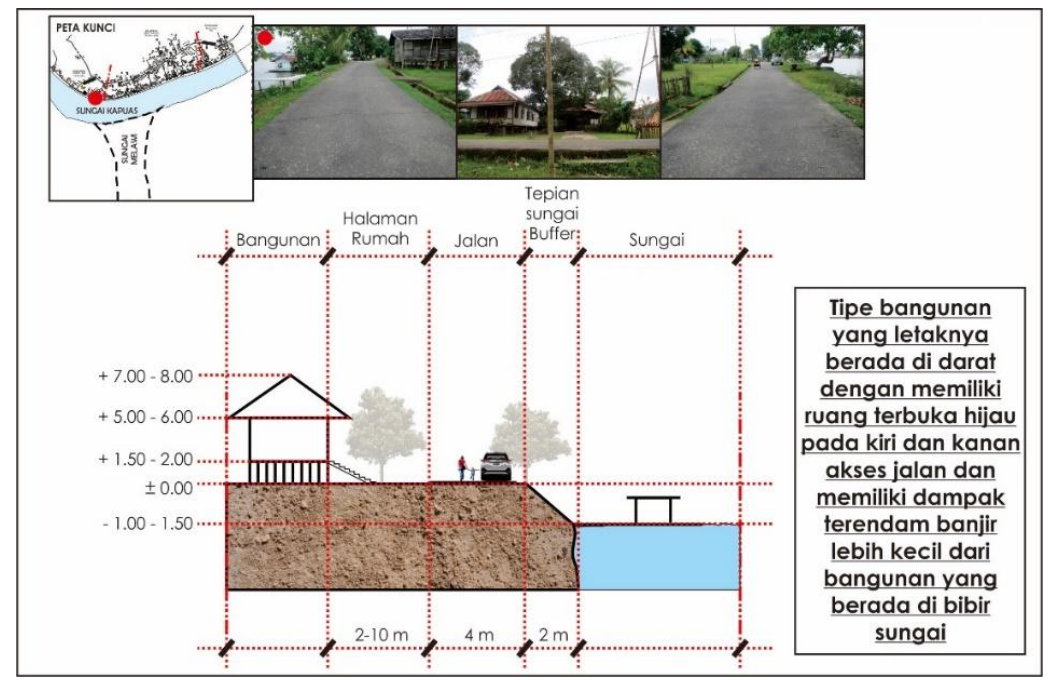

Gambar 4. Ilustrasi Tipe Bangunan yang berada di darat pada Kelurahan Kapuas Kiri Hilir, Kelurahan Menyumbung Tengah dan Kelurahan Ulak Jaya Sumber: Penulis, 2018 


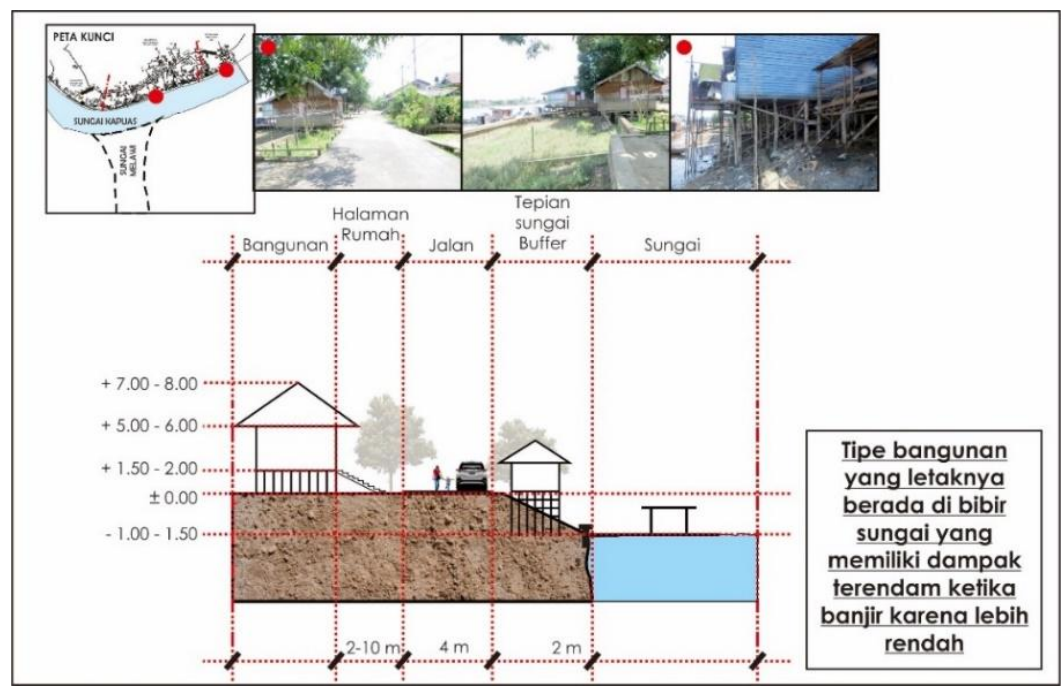

Gambar 5. Ilustrasi Tipe Bangunan yang berada di Bibir Sungai pada Kelurahan Kapuas Kiri Hilir, Kelurahan Menyumbung Tengah dan Kelurahan Ulak Jaya

Sumber: Penulis, 2018

Tipe bangunan yang berada di darat dan di bibir sungai memiliki kesamaan model bangunan. Model bangunan yang berada pada Kelurahan Kapuas Kiri Hilir, Kelurahan Menyumbung Tengah dan Kelurahan Ulak Jaya dominan dengan bentuk bangunan Rumah Panggung (Gambar 6). Bangunan yang menyediakan ruang atau yang disebut juga kolong di bawah bangunan. Tujuan masyarakatnya membangun rumah dengan bentuk panggung merupakan salah satu antisipasi agar air tidak masuk ke dalam rumah ketika kenaikan permukaan air naik hingga banjir. Selain itu, pada bagian kolong bangunan berfungsi sebagai tempat penyimpanan kayu-kayu untuk persiapan ketika kenaikan permukaan air naik hingga banjir.

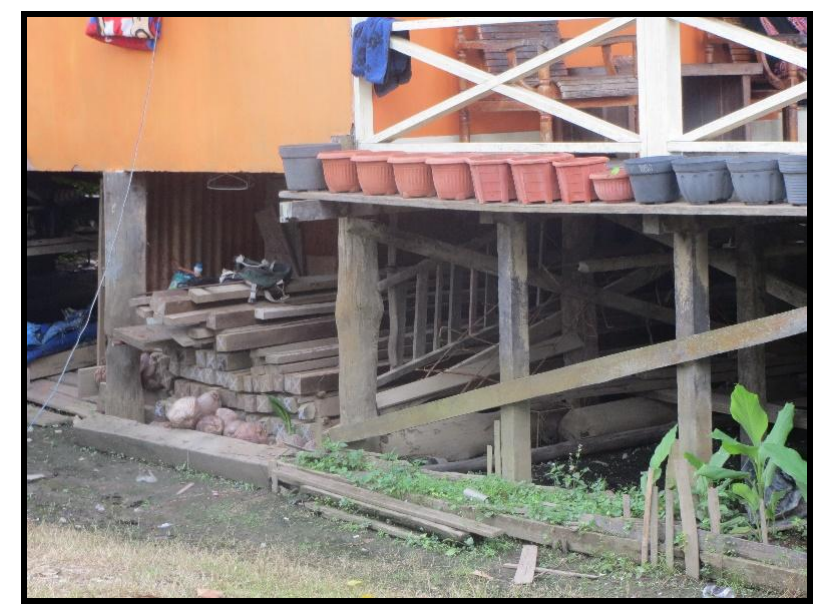

Gambar 6. Tempat Penyimpanan Kayu Papan di Bawah Kolong Bangunan pada Kelurahan Kapuas Kiri Hilir, Kelurahan Menyumbung Tengah dan Kelurahan Ulak Jaya Sumber: Penulis, 2018

Kayu-kayu yang disimpan tersebut akan menjadi papan pijakan sebagai sirkulasi tambahan bagi masyarakat ketika banjir terjadi. Ketika hujan yang terjadi secara terus menerus ataupun terdapat banjir kiriman dari daerah hulu sungai, maka masyarakat sulit untuk mengakses jalur 
daratan karena banjir. Kayu-Kayu yang disebut Titian oleh masyarakat di sana akan dipasang di atas batas air sungai naik atau banjir.

\section{Teknis Penyelamatan}

Teknis Penyelamatan ketika bencana banjir terjadi pada Kelurahan Kapuas Kiri Hilir, Kelurahan Menyumbung Tengah dan Kelurahan Ulak Jaya, yaitu menggunakan titian (kayu-kayu papan) (Gambar 7). Kayu-kayu tersebut dapat dibongkar pasang. Adapun masyarakat yang memiliki rumah tingkat dua dapat menetap di lantai dua rumahnya.

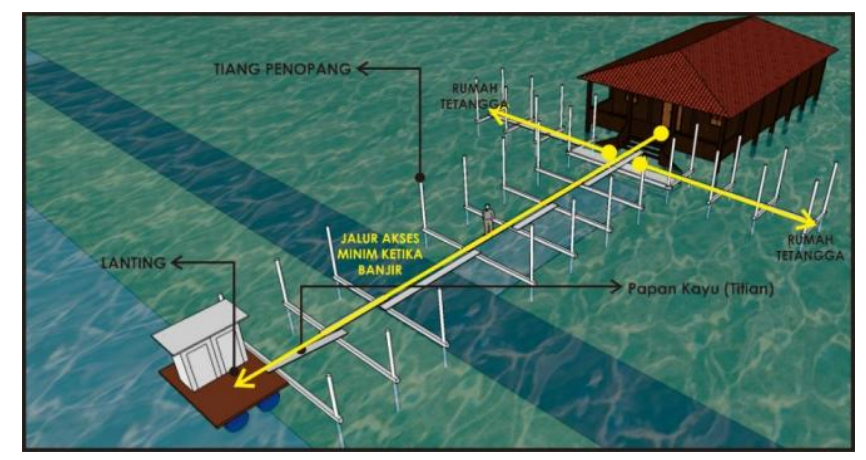

Gambar 7. Ilustrasi Jalur Sirkulasi Penyelamatan Bencana pada Kelurahan Kapuas Kiri Hilir,

Kelurahan Menyumbung Tengah dan Kelurahan Ulak Jaya

Sumber: Penulis, 2018

Ketika banjir terjadi, masyarakat sulit untuk mengakses jalanan yang terendam oleh banjir. Sehingga sirkulasi satu-satunya yaitu melalui air. Transportasi air satu-satunya yang dapat digunakan yaitu kapal atau sampan milik masyarakat setempat yang biasa disebut tambang. Sebagian besar masyarakat setempat memiliki sampan kecil yang disediakan untuk dipakai menyeberang sungai untuk membeli kebutuhan sehari-hari.

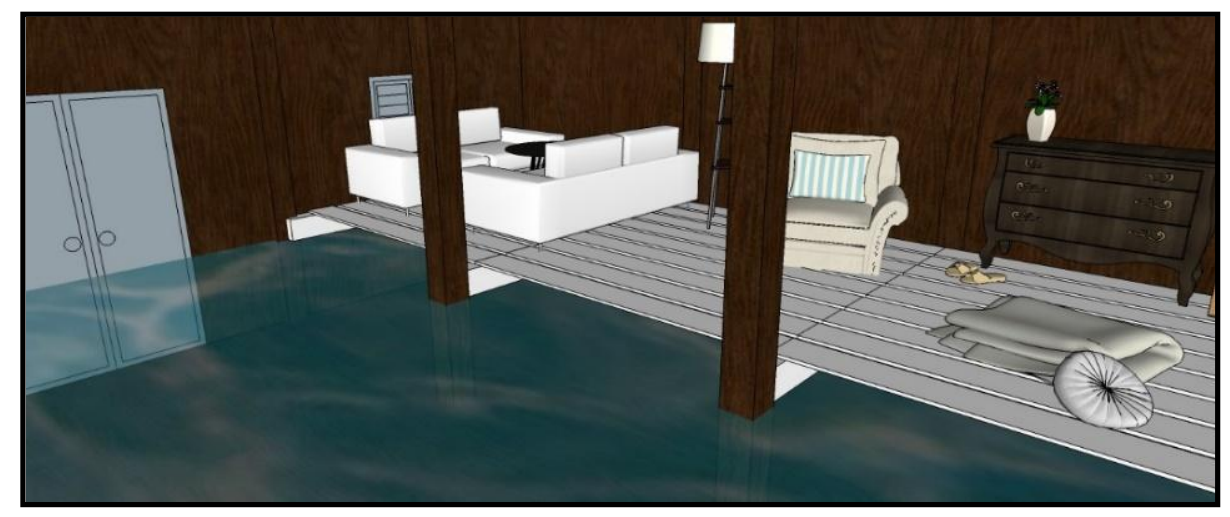

Gambar 8. Ilustrasi Pemasangan Titian (Kayu Papan) saat Penyelamatan Bencana pada Kelurahan Kapuas Kiri Hilir, Kelurahan Menyumbung Tengah dan Kelurahan Ulak Jaya

Sumber: Penulis, 2018

\section{Pasang surut permukaan air}

Pasang surut permukaan air pada Kelurahan Kapuas Kiri Hilir, Kelurahan Menyumbung Tengah dan Kelurahan Ulak Jaya sering terjadi pada musim hujan. Ketinggian maksimum kenaikan permukaan air yang di capai yaitu sekitar 1-1.5m dari permukaan air normal. Kenaikan permukaan 
air yang mencapai $\pm 1-1.5 \mathrm{~m}$ belum menyebabkan banjir pada wilayah sekitarnya. Tetapi masyarakat sudah mulai siaga, karena kenaikan permukaan air yang bertambah akan menjadi bencana banjir yang merendam segala sirkulasi jalan maupun menghambat segala aktivitas sehari-hari. Jika air sungai naik 2-3 m dari permukaan air sungai normal, maka sirkulasi jalan akan tertutup dan kendaraan darat tidak dapat digunakan. (Lihat Gambar 9)

Masyarakat setempat menjadikan Lanting sebagai acuan atau ukuran dalam memperkirakan kenaikan permukaan air sungai, karena sifat rumah lanting yang terapung. Menurut masyarakat setempat, jika atap lanting sudah mulai terlihat dari teras depan rumah, maka itu merupakan tanda permukaan air sungai sedang naik.

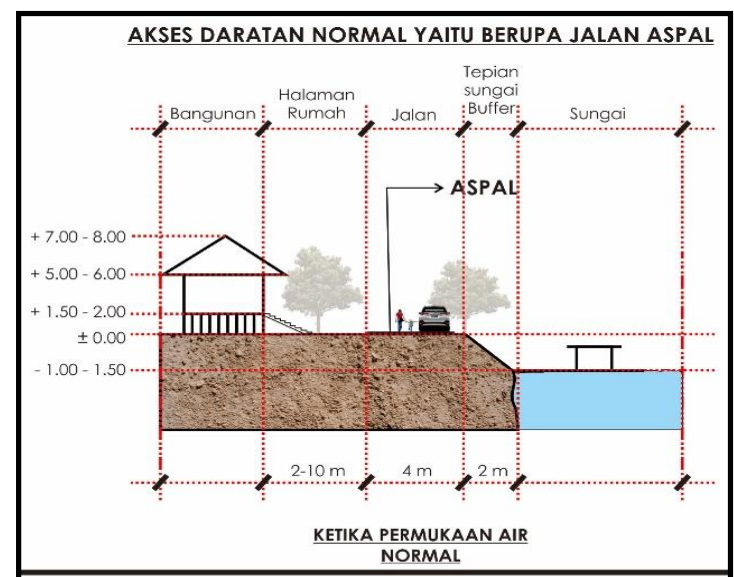

AKSES DARATAN NORMAL YAITU BERUPA JALAN ASPAL

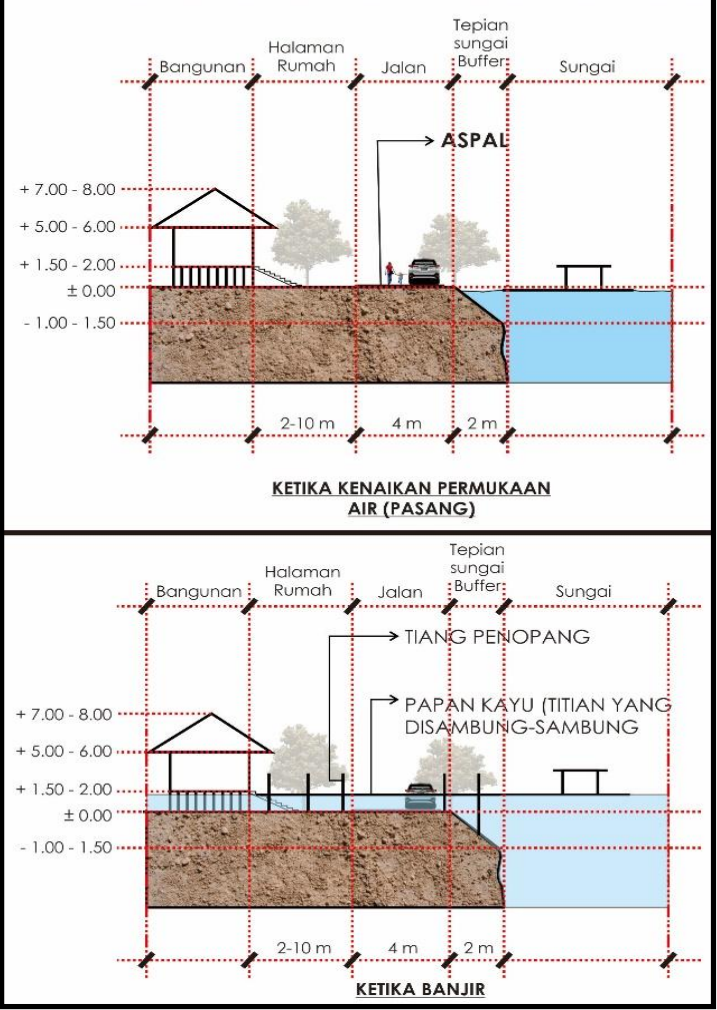

Gambar 9. Ilustrasi Pasang Surut Permukaan Air di Kelurahan Kapuas Kiri Hilir, Kelurahan Menyumbung Tengah dan Kelurahan Ulak Jaya Sumber: Penulis, 2018 


\section{Kesimpulan}

Masyarakat Kelurahan Kapuas Kiri Hilir, Kelurahan Menyumbung Tengah dan Kelurahan Ulak Jaya di Sintang merasakan bencana yang sering terjadi yaitu banjir dan kenaikan permukaan air (air pasang) yang membuatnya menjadi genangan air. Maka persepsi masyarakat tersebut berhubungan dengan kondisi fisik masing-masing lokasi, yaitu:

1. Pada Kelurahan Kelurahan Kapuas Kiri Hilir, Kelurahan Menyumbung Tengah dan Kelurahan Ulak Jaya di Sintang terletak dekat dengan hulu sungai yang menyebabkan volume air bertambah banyak akibat limpahan dari hulu sungai sehingga mengakibatkan banjir.

2. Masyarakat menganggap banjir berdampak negatif, karena merusak bangunan dan merendam ruang sirkulasi dan ruang terbuka. Ruang sirkulasi dan ruang terbuka merupakan bagian fisik kawasan yang berperan penting dalam aktivitas sehari-hari, dan ketika banjir maka segala aktivitas akan terhambat. Tipe sirkulasi dan ruang terbuka berupa jalan aspal yang merupakan fasilitas penting dalam sirkulasi kendaraan darat dan sirkulasi masyarakat untuk pergi bekerja dan beraktivitas lainnya.

3. Masyarakat melakukan suatu upaya penanggulan banjir untuk dapat beraktivitas memenuhi kebutuhan sehari-hari, dengan cara mendirikan titian (kayu papan) yang disusun di atas air. Serta melihat fisik bangunan yang berbentuk rumah panggung, terdapat bagian bawah bangunan yang berfungsi sebagai tempat penyimpanan kayu-kayu titian. Hal ini secara tidak langsung telah menjadi salah satu upaya penanggulangan dan antisipasi masyarakatdalam menangani permasalahan ketika mengalami banjir.

\section{Daftar Pustaka}

Haifani, Akhmad Muktaf. (2008). Manajemen Resiko Bencana Gempa Bumi (Studi Kasus Gempabumi Yogyakarta 27 Mei 2006). Seminar Nasional IV Sdm Teknologi Nuklir Yogyakarta, 25-26 Agustus 2008 ISSN 1978-0176

Haryanti, Dini Tri. (2008). Kajian Pola Pemanfaatan Ruang Terbuka Publik Kawasan Bundaran Simpang Lima Semarang. Semarang: Universitas Diponegoro, Tesis

Jokowinarno, Dwi. (2011). Mitigasi Bencana Tsunami Di Wilayah Pesisir Lampung. Lampung: Jurnal Rekayasa Vol. 15 No. 1, April 2011

Krier, Rob. (1979). Urban Space. New York: Rizzoli.

Nugroho, Erik Kado, Endang Pudjihartati, Bistok Hasiholan Simanjuntak. (2014). Redesain Sistem Sirkulasi, Parkir Dan Rambu-Rambu Lanskap Kampus 1 Universitas Kristen Satya Wacana. AGRIC Vol.26, No. 1 \& 2, Juli - Desember 2014: 61 - 74

Nurdiyana. (2017). Persepsi Mahasiswa Ilmu Komunikasi Terhadap Tayangan Stand Up Comedy Kompas
TV Sebagai Program Komedi Populer Di Indonesia. Makassar: Universitas Hasanuddin

Rachmatullah, Michael, Octavianus H.A. Rogi, Sonny Tilaar. (2016). Evaluasi Kebijakan Pola Ruang Dan Struktur Ruang Berbasis Mitigasi Bencana Banjir (Studi Kasus : Kota Palu). Manado: Universitas Sam Ratulangi

Rahmat, Jalalludin. (2004). Psikologi Komunikasi. Bandung, Remaja Rosdakarya

Subiyantoro, I. (2010). Selayang Pandang tentang Bencana. Jurnal Dialog Penanggulangan Bencana, 1, 43-46

Walgito, Bimo. (2004). Pengantar Psikologi Umum. Yogyakarta: Andi Ofset

Wardhana, W. A. (2010). Dampak Pemanasan Global. Yogyakarta: Penerbit Andi

Wikantiyoso, Respati. (2010). Mitigasi Bencana Di Perkotaan; Adaptasi Atau Antisipasi Perencanaan Dan Perancangan Kota ? (Potensi Kearifan Lokal Dalam Perencanaan Dan Perancangan Kota Untuk Upaya Mitigasi Bencana). Malang: Volume:II, Nomor: 1. Halaman: 18 - 29 